\title{
Forage Quality of Colorado Pastures
}

\section{G. THOMPSON AND A. D. DOTZENKO}

Highlight: Irrigated pastures located throughout Colorado were evaluated for quality during the 1974 and 1975 growing seasons. The locations represent the diverse climatic and soil conditions found throughout the state. Twelve chemical components were evaluated from each pasture sample obtained over a 5-month period for both years. The relationships of the various chemical components to each other, to time of sampling, and in particular to in vitro digestible dry matter (IVDDM) were determined. Crude protein, neutral detergent fiber, acid detergent fiber, hemicellulose, cellulose, lignin, silica, IVDDM, calcium, and magnesium showed significant changes during the growing seasons of both years while phosphorus and potassium did not. Acid detergent fiber and silica were shown to have significant positive correlation with time of sampling while crude protein and IVDDM had significant negative correlations during both growing seasons. The best predicators of IVDDM in regression analyses were acid detergent fiber, time of sampling, and hemicellulose. The acid detergent fiber concentration accounted for $60 \%$ of the variation in digestibility. The time of sampling and the percentages of acid detergent fiber and hemicellulose provided a reliable estimate of digestibility of irrigated pastures in Colorado.

With the increased demand and cost of cereal grains, more attention must be given to forages, especially those produced on pastures, to provide the necessary nutrients for livestock production. It has been estimated (Hodgson 1968) that forages provide approximately $70 \%$ of the nutrients fed to ruminants. The potentials are great for improving the yield, quality, and utilization of pastures and thereby increasing the production of meat, milk, and wool products by ruminant animals. In the State of Colorado more land is utilized for the grazing of animals than for any other agricultural purposes. Nutritive value characteristics of Colorado-produced forages are not well documented, and this study is an attempt to gain a better understanding of the quality potentials.

\footnotetext{
The authors are, respectively, former graduate rescarch assistant and professor, Department of Agronomy, Colorado State University, Fort Collins 80523.

This research is a contribution from the Department of Agronomy. Colorado State University Experiment Station, Fort Collins, containing portions of a thesis submitted by the senior author as partial requirement for the $\mathrm{PhD}$ degree. Published with the approval of the Director of the C.S.U. Exp. Sta. as Scientific Series Paper No. 2205.

Manuscript received September 15, 1976.
}

Numerous chemical and bioassay methods have been published for evaluating forage quality and for predicting digestibility (Barnes 1973). The Tilley and Terry (1963) two-stage technique for estimating digestibility is used quite extensively, but is time consuming, requires extensive laboratory facilities, and is expensive because of the need for maintaining fistulated animals. Goering and Van Soest (1970) have also developed a comprehensive system of feed analysis applicable to the measurement of digestibility of forages. A good, reliable regression equation would be very useful to predict digestibility from the concentration of a few forage components.

The objectives of this study were: (1) to determine the quality components of the irrigated pastures in Colorado; (2) to evaluate the effect of seasonal growth on the various forage components, and in turn relate these factors to in vitro digestible dry matter; and (3) to develop a reliable regression equation for estimating digestibility.

\section{Materials and Methods}

Twenty-three irrigated pastures in 1974 and twenty-one pastures in 1975 repre- senting a cross section in environmental conditions and systems of management were selected for evaluation. Species consisted of nine grasses and four legumes with the majority of the pastures consisting of alfalfa (Medicago sativa L.), bromegrass (Bromus inermis Leyss.), and orchardgrass (Dactylis glomerata L.) in varying proportions.

Samples from the pastures were harvested by using shears or a sickle at approximately 30-day intervals from May through September. An effort was made to harvest the pasture forage at the height the cattle were grazing. Duplicate samples of the oven-dried $\left(65^{\circ}-70^{\circ} \mathrm{C}\right)$ forage were analyzed for crude protein, cell wall constituents or neutral detergent fiber (NDF), acid detergent fiber (ADF), hemicellulose, cellulose, lignin, silica, in vitro digestible dry matter (IVDDM), calcium, magnesium, phosphorus, and potassium.

Nitrogen percentages were determined by the micro-Kjeldahl technique. Neutral detergent fiber (NDF), acid detergent fiber (ADF), hemicellulose, cellulose, lignin, and silica were determined as outlined by Goering and Van Soest (1970) and Van Soest and Wine (1968). In vitro digestible dry matter (IVDDM) was determined using the modified Tilley and Terry two-stage procedure (1963) with direct acidification and addition of pepsin as described by Alexander and McGowan (1961). After a wet digestion using nitric and perchloric acids, phosphorus was detcrmined using the procedure described by Barton (1948). Calcium, magnesium, and potassium were determined with a Perkin-Elmer atomic absorption spectrophotometer as outlined by David (1959) and Allan (1958).

Statistical analyses were made on all the forage components and IVDDM with respect to locations and times of sampling in 1974 and 1975. Tukey's HSD was used to determine significant differences. Simple, stepwise, and multiple regression analyses were performed in which time of sampling $($ May $=1$, June $=2, \ldots$ Sept.$=5)$ was deleted and included as a free independent variable with the other measured components and IVDDM as the dependent variable. 
Table 1. Mean percentages of chemical constituents and IVDDM of oven-dry forages from irrigated pastures sampled at monthly time intervals for the combined years of 1974 and 1975.

\begin{tabular}{lcccccc}
\hline \hline Variable & May & June & July & August & September & HSD $^{1}$ \\
\hline Crude protein & 21.2 & 17.0 & 16.1 & 18.2 & 15.8 & 3.3 \\
Neutral detergent fiber & 49.2 & 55.3 & 57.5 & 54.9 & 54.7 & 4.6 \\
Acid detergent fiber & 29.1 & 34.3 & 36.0 & 35.4 & 35.4 & 3.0 \\
Hemicellulose & 20.1 & 20.9 & 21.5 & 19.5 & 19.3 & 2.7 \\
Cellulose & 22.1 & 24.8 & 26.5 & 25.5 & 24.2 & 2.1 \\
Lignin & 4.2 & 5.3 & 5.6 & 5.6 & 5.2 & 0.7 \\
Silica & 2.2 & 3.7 & 3.5 & 3.9 & 5.5 & 1.0 \\
NDDM & 66.9 & 62.6 & 60.2 & 60.0 & 57.4 & 3.5 \\
Calcium & 0.52 & 0.43 & 0.50 & 0.68 & 0.72 & 0.18 \\
Magnesium & 0.18 & 0.13 & 0.13 & 0.16 & 0.17 & 0.04 \\
Phosphorus & 0.27 & 0.27 & 0.27 & 0.26 & 0.25 & NS \\
Potassium & 2.74 & 2.58 & 2.92 & 3.00 & 2.70 & NS \\
\hline
\end{tabular}

${ }^{1}$ Tukey's HSD values (5\% level).

\section{Results and Discussion}

Monthly values of eleven constituents and IVDDM averaged for both years and locations are reported in Table 1. With the exception of phosphorus and potassium all constituents showed significant variations with time of sampling. Calcium, magnesium, phosphorus, and potassium were all well within the ranges recommended for good ruminant nutrition.

Silica and IVDDM relationships to time of sampling for both years show a linear nature, and their relationship with time of sampling was found to be similar in both years. As indicated (Table 1), the pasture forages were continually incorporating silica throughout both growing seasons. The silica present in plant material may exert much the same effect as lignin in reducing digestibility. Van Soest and Jones (1968) have reported an average decrease of 3.0 units in digestibility per unit of silica in the dry matter of some grasses. This same relationship exists in this study.

With each subsequent time of sampling, IVDDM continued to decline even though the irrigated pastures were being grazed. It appears that the perennial forages reacted by an increase in structural components as the grazing season progressed (Table 1). A decrease in IVDDM is associated with an increase in the structural components of NDF, ADF, hemicellulose, cellulose, lignin, and silica as shown in Table 2 . The significant negative correlation values obtained between the structural constituents and IVDDM reflect the adverse effect of these factors on nutritive value. NDF and ADF were found to have the highest degree of correlation with IVDDM with $r$-values of 0.73 and 0.77 , respectively. A close positive deleted as a variable were less accurate than any of the equations containing this variable. By including the three chemical components and time of sampling, $72 \%$ of the variation in IVDDM could be explained. The regression equation was as follows: IVDDM $=98.86+(-1.18)$ Time $+(-1.1 \mathrm{ADF}$ $+(-.38) \mathrm{HC}+(.58) \mathrm{C}$

where Time $=$ months, $\mathrm{ADF}=$ acid detergent fiber, $\mathrm{HC}=$ hemicellulose, and $C=$ cellulose. The standard error of the estimate of this regression equation was 3.57. The variables in the equation were similar to those obtained for the individual years.

Since the factor of cellulose was already being accounted for in the ADF fraction and its addition into the regression equation had very little effect on increasing the total $R$ value, therefore a stepwise regression analysis was run excluding cellulose. The resulting equation with the standard error of the coefficients and standard error of the estimate is as follows: components. These equations formulated to find which factors and in what combinations would give the best prediction of IVDDM. Table 3 gives a summary of the stepwise regression analysis performed on the data for 1974 and 1975. ADF was the first variable to enter the equation with a $r^{2}$ value (R) of 0.60 . Time of sampling entered next, followed by hemicellulose and cellulose. No other variables were entered or removed from the regression analysis with the $F$ value set at the $5 \%$ level of probability. The equations with time

$$
\text { IVDDM }=99.55+(-1.39) \text { Time }+
$$$$
(-.81) \mathrm{ADF}+(-.29) \mathrm{HC}
$$

Where time $=$ months with a standard error of 0.22

$$
\begin{aligned}
\text { ADF }= & \text { acid detergent fiber with a stan- } \\
& \text { dard error of } 0.59 \\
H C= & \begin{array}{l}
\text { hemicellulose with a standard } \\
\text { error of } 0.55
\end{array}
\end{aligned}
$$

IVDDM = in vitro digestible dry matter

\begin{tabular}{|c|c|c|c|c|c|c|c|}
\hline & NDF & ADF & $\mathrm{HC}$ & $\mathrm{C}$ & $\mathrm{L}$ & $\mathrm{S}$ & IVDDM \\
\hline Crude protein (CP) & $-.66^{*}$ & $-.70^{*}$ & $-.40^{*}$ & $-.71 *$ & $-.34 *$ & -.09 & $.53 *$ \\
\hline Neutral detergent fiber (NDF) & & $.81^{*}$ & $.84^{*}$ & $.84^{*}$ & $.44^{*}$ & .04 & $-.73^{*}$ \\
\hline Acid detergent fiber (ADF) & & & $.36^{*}$ & $.88^{*}$ & $.63^{*}$ & $.27^{*}$ & $-.77^{*}$ \\
\hline Hemicellulose (HC) & & & & $.51 *$ & .11 & -.19 & $-.44 *$ \\
\hline Cellulose $(\mathrm{C})$ & & & & & $.45^{*}$ & -.10 & $-.63 *$ \\
\hline Lignin (L) & & & & & & -.14 & $-.50^{*}$ \\
\hline Silica (S) & & & & & & & $-.30^{*}$ \\
\hline
\end{tabular}
with a standard error of the estimate of 3.69

Table 2. Simple correlation ( $r$ ) values of various chemical components and IVDDM of forage samples at monthly intervals from irrigated pastures during 1974 and 1975.

I *Significant at the .01 level.

Table 3. Summary table of stepwise regression analysis for the combined years of 1974 and 1975 with time of sampling freed as an independent variable and IVDDM as the dependent variable.

\begin{tabular}{llllrr}
\hline \hline Step no. & Variable entered & $\mathrm{r}$ & $\mathrm{r}^{2}$ & Increase in $\mathrm{r}^{2}$ & $F$ value $^{1}$ \\
\hline 1 & Acid detergent fiber & .77 & .60 & .60 & 249.05 \\
2 & Time of sampling & .80 & .65 & .05 & 32.69 \\
3 & Hemicellulose & .83 & .70 & .05 & 27.71 \\
4 & Cellulose & .85 & .72 & .02 & 12.98 \\
\hline
\end{tabular}

${ }^{1} F$ value in this program to enter or remove each variable was 4.00 . 
Only minimal accuracy is sacrificed by the elimination of cellulose. It appears that the three-variable equation with time of sampling, ADF, and hemicellulose would have more application considering the additional time and expense needed in the laboratory analysis for cellulose.

A summative equation based on the assumption that individual chemical factors additively limit nutritive value of a feed has also been proposed by Goering and Van Soest (1970). However, their equation includes cell contents, estimated digestion, coefficient of cell walls, and metabolic fecal losses which require considerable more time and expense in obtaining an estimate of digestibility. Campbell and Dotzenko (1975) produced a summative equation for pasture forages in northeastern Colorado that is similar to the one nresented hv this studv. Although their equation showed higher correlation to IVDDM, it would be restricted in its use because of the limited number of pastures sampled, as well as being from the same general locality. By increasing the number of pastures sampled at several locations over a wide area, some of the accuracy in predicting IVDDM was lost in this study; but the application of this predictive equation could now encompass a greater range of irrigated pastures in Colorado.

\section{Literature Cited}

Alexander, R. H., and M. McGowan. 1961. A filtration process for the in vitro determination of digestibility of herbage. J. Brit. Grassl. Soc. 16:275-276.

Allan, J. E. 1958. Atomic-absorption spectrophotometry with special reference to the determination of magnesium. Analyst. 83:466-471.

Barnes, R. F. 1973. Laboratory methods of evaluating feeding value of herbagc. p. 179-
214. In: Butler, B. W. and R. W. Bailey (eds.). Chemistry and Biochemistry of Herbage. Vol. 3. Academic Press, New York.

Barton, C. J. 1948. Photometric analysis of phosphate rock. Anal. Chem. 20:1068-1073.

Campbell, I. S., and A. D. Dotzenko. 1975. Evaluating forage quality of pastures. J. Range Manage. 28:149-151.

David, D. J. 1959. Determination of calcium in plant material by atomic absorption spectrophotometry. Analyst 84:536-545.

Goering, H. K., and P. J. Van Soest. 1970. Forage fiber analyses. U.S. Dep. Agr., Agr. Res. Serv., Agr. Handb. 379.

Hodgson, H. J. 1968. Forages-their present importance and future potentials. Agr. Sci. Rev. 6(2):23-30.

Tilley, J. M., and R. A. Terry. 1963.A twostage technique for the in vitro digestion of forage crops. J. Brit. Grassl. Soc. 18:104-111.

Van Soest, P. J., and L. N. P. Jones. 1968. Effect of silica in forages upon digestibility. J. Dairy Sci. 51:1644-1649.

Van Soest, P. J., and R. H. Wine. 1968. Determination of lignin and cellulose in aciddetergent fiber with permanganate. J. Ass. Offic. Anal. Chem. 51:780-785. 